\title{
Moisture and Salinity Drive the Vegetation Composition of Wadi Hargan, Riyadh, Saudi Arabia
}

\author{
Ahmed M. Abd-ElGawad 1,2,*®D, Abdulaziz M. Assaeed ${ }^{1}{ }^{1}$, Saud L. Al-Rowaily ${ }^{1}$, Basharat M. Dar ${ }^{1}$ \\ and Jahangir A. Malik ${ }^{1}$ \\ 1 Plant Production Department, College of Food \& Agriculture Sciences, King Saud University, P.O. Box 2460, \\ Riyadh 11451, Saudi Arabia; assaeed@ksu.edu.sa (A.M.A.); srowaily@ksu.edu.sa (S.L.A.-R.); \\ bdar@ksu.edu.sa (B.M.D.); jmalik@ksu.edu.sa (J.A.M.) \\ 2 Department of Botany, Faculty of Science, Mansoura University, Mansoura 35516, Egypt \\ * Correspondence: aibrahim2@ksu.edu.sa; Tel.: +966-5626-80864
}

check for updates

Citation: Abd-ElGawad, A.M.; Assaeed, A.M.; Al-Rowaily, S.L.; Dar, B.M.; Malik, J.A. Moisture and Salinity Drive the Vegetation Composition of Wadi Hargan, Riyadh, Saudi Arabia. Diversity 2021, 13, 587. https://doi.org/10.3390/d13110587

Academic Editor: Michael Wink

Received: 6 October 2021

Accepted: 15 November 2021

Published: 18 November 2021

Publisher's Note: MDPI stays neutral with regard to jurisdictional claims in published maps and institutional affiliations.

Copyright: (c) 2021 by the authors. Licensee MDPI, Basel, Switzerland. This article is an open access article distributed under the terms and conditions of the Creative Commons Attribution (CC BY) license (https:/ / creativecommons.org/licenses/by/ $4.0 /)$.

\begin{abstract}
Wetlands are represented in Saudi Arabia in the form of mangrove, sabkha, and wadi (valleys) systems, and these habitats are considered as a sanctuary for biodiversity. The present study aimed to identify different vegetation groups in a wetland site in Wadi Hargan near Alqurainah, Riyadh, Saudi Arabia, and to relate different plant communities and plant diversity to soil moisture, salinity, and other soil properties. Floristic analysis and vegetation structure were investigated within 15 stands along the wadi and were subjected to correlation analysis with soil factors via multivariate analysis. The floristic survey revealed the presence of 111 plant species belonging to 39 families. The most represented families were Asteraceae, Poaceae, Brassicaceae, Caryophyllaceae, and Papilionaceae, which accounted for the largest proportion (55.4\%) of the total species. The therophytes were the dominant life form, where they were represented by $46.9 \%$ of the total number of species. The application of cluster analysis (TWINSPAN) to the importance value of each species based on the relative cover and density led to the recognition of four plant communities: (A) Phragmites australis-Tamarix nilotica community, (B) Zygophyllum coccineum-Acacia gerrardii community, (C) Lycium shawii-Zygophyllum coccineum community, and (D) Rhazya stricta community. The soil analysis and correlation test revealed significant variations in the content of salinity, moisture, $\mathrm{CO}_{3}$, $\mathrm{Cl}, \mathrm{SO}_{4}, \mathrm{Ca}, \mathrm{Mg}$, and $\mathrm{Na}$ among the plant communities. It can be concluded that soil moisture and salinity factors were the fundamental driving forces for plant community structure in the studied wadi. The wadi was moderately grazed, mainly by camels; thereby, the invasive plant Rhazya stricta dominated the central region of the wadi. Also, human interference was observed at the end of the wadi, where some weeds sprouted such as Malva parviflora. The presence of those two rare wetland species, Adiantum capillus-veneris and Ficus salicifolia, in the study area, showed the unique properties of the studied wadi and necessitate an urgent biodiversity conservation action to protect its natural vegetation from overgrazing and human interference.
\end{abstract}

Keywords: wetlands; salinity; conservation; acacias; desert ecosystem; Rhazya stricta

\section{Introduction}

Despite the arid climate of Saudi Arabia, there are several wetlands predominant in mangrove, sabkha, and wadi (valleys) systems [1]. Wetlands are considered as analogous to keystone species in that they play a disproportionately large role within their ecosystem relative to their small size [2-4]. Wetlands play an important ecological role in carbon sequestration [5] and biodiversity conservation [6-8]. They support unique assemblage of vegetation [9] and maintain suitable habitat for migrating birds [10]. Wetlands have a broad spectrum in Saudi Arabia, where they can be categorized into eight systems: coastal, sabkha, karst, mountain, geothermal, wadi, and man-made systems [1,11].

Plant community distribution is controlled by many processes, including biotic processes, such as plant dispersal, growth, herbivory, and mortality, as well as abiotic factors 
and processes, such as substrate, topography, climate, or disturbance. Therefore, the structure of a plant community is the product of these complex and interacting processes [12]. The two most important abiotic factors controlling plant communities in arid areas are soil moisture and salinity [13]. Soil moisture plays a crucial role in shaping desert plant communities [14]. Soil moisture availability controls species distribution and richness as few species can withstand extremely poor water conditions [15]. Halophyte species distribution are mostly determined by soil moisture and salinity [16-18]. However, Xi, et al. [17] suggested that the water gradients had a more significant and more direct effect than salinity gradients on plant species and communities, but it depends on scale and ecosystem types [19].

Wetlands are prone to the impact of human activities outside their boundaries that alter their hydrologic system [20,21]. Such activities include changes in watershed land use, road construction, and other factors or processes that affect water recharge or subsurface flow paths. Conservation of wetland systems to sustain freshwater biota poses a challenge to scientists and decision-makers to realize linkages required to control damaging factors and restore their impacts. Evaluation and monitoring of wetland vegetation help close critical gaps of information needed to make sound future conservation decisions. Few studies have been done regarding Saudi Arabia's wetlands services their sustainable conservation and use [1]. The study and evaluation of wetlands as hotspots for biodiversity will help in supporting their conservation and uses, as well as provide substantial information for scientists, policymakers, and stakeholders for sustainable management. The vegetation analysis of 63 sabkhas in the central region of Saudi Arabia showed that soil salinity, texture and nutrients were the main factors affecting plant distribution [22]. A study by Galal, et al. [23] showed an alteration of the natural status of the desert-wetland ecosystems, southwestern Saudi Arabia has occurred. Thus, urgent conservation action is required. Despite their ecological importance, our knowledge and understanding of desert wetlands are limited. According to our preliminary field observation of Wadi Hargan, we recorded some rare species such as Adiantum capillus-veneris and Ficus salicifolia which indicate the unique properties of this wadi, that could be ascribed to the water source. We hypothesize that the environmental factors; soil moisture and salinity discriminate best between the vegetation types identified by cluster analysis and explain a high proportion in the variability of plant species richness and stand structure. The objectives of this work were: (1) to identify different vegetation groups in a wetland site in Wadi Hargan near Alqurainah, Riyadh, Saudi Arabia, and (2) to relate different plant communities to soil moisture, salinity, and other soil properties.

\section{Materials and Methods}

\subsection{The Study Area}

The location of Wadi Hargan is approximately 55 km northwest of Riyadh City, Saudi Arabia situated between $25^{\circ} 03.975^{\prime} \mathrm{N}$ and $46^{\circ} 12.157^{\prime} \mathrm{E}$ (Table S1). The Wadi is surrounded by flat rocky beds devoid of any vegetation. Flat rocky beds bordering this wadi from all directions are largely exposed with almost no soil cover and have insufficient groundwater to facilitate vegetation. The wadi has varying altitudes ranging from 824 to 797 m.a.s.l. in the upstream and downstream areas, respectively. The wadi was selected for study because of its different vegetation diversity in spite of having arid conditions around. Water seeps from the upstream bottom base of the wadi forming a runnel flowing all along the study area, thus giving it a form of a wetland ecosystem with highly saline groundwater in gypsum formation. The area has a mean maximum temperature of $43^{\circ} \mathrm{C}$ in August and an average minimum of $9^{\circ} \mathrm{C}$. in January. The average total annual rainfall is $\approx 130 \mathrm{~mm}$ [24].

\subsection{Vegetation Analysis}

Fifteen stands were randomly selected along the wadi to represent the study area, during spring 2019, taking patchy vegetation into consideration (Figure 1). In each stand, a $20 \times 20 \mathrm{~m}$ quadrat was used. In each quadrat, the plant species were listed, and the 
density was determined according to Bonham [25], while the cover of each species was estimated according to the Braun-Blanquet scale [26].

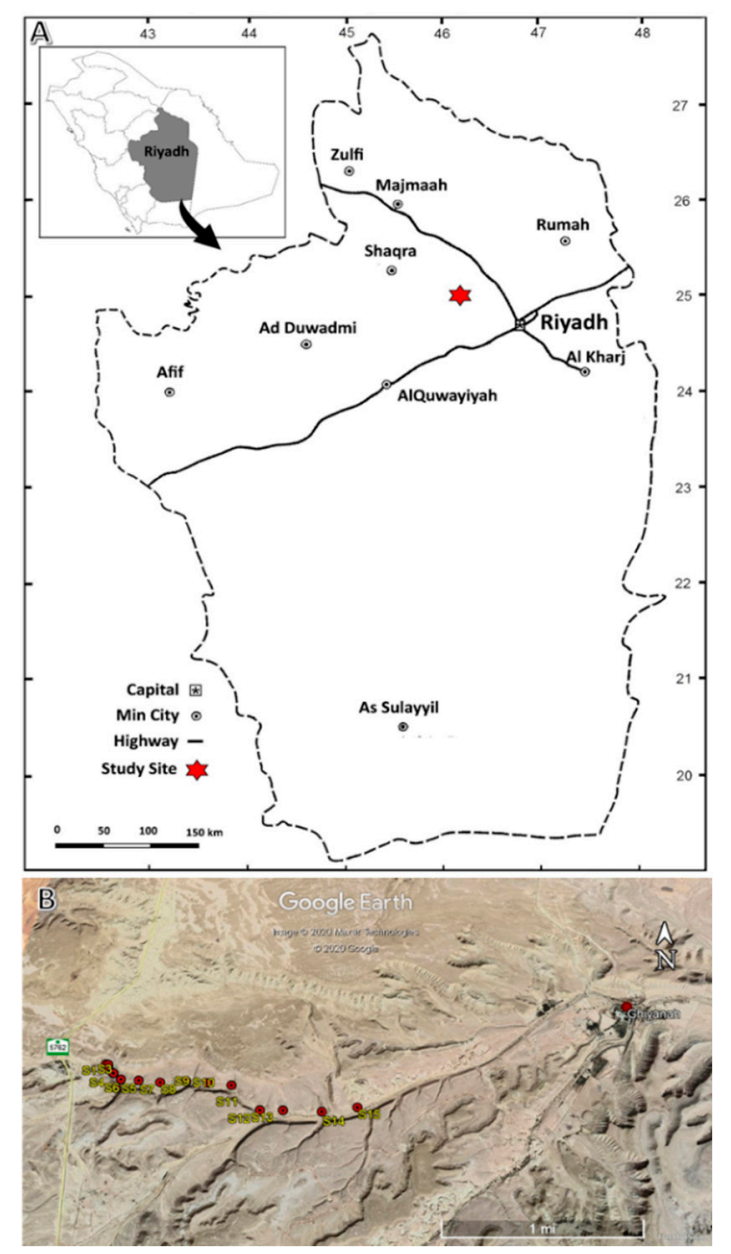

Figure 1. (A) Map of Riyadh region showing the study area indicated by star $(\star),($ B) Google Earth map showing the sampled stands $(\bullet)$.

The importance value was calculated by the summation of the relative value of density and cover of each plant species. The nomenclature of plant species was assessed according to Collenette [27] and Chaudhary [28], while the life forms of the species were identified according to Raunkiaer [29]. The chorotypes of all species were made to assign the recorded species to World Geographical Groups according to Zohary [30].

\subsection{Soil Analysis}

Within each quadrat, three soil samples, at a depth of $10-40 \mathrm{~cm}$, were collected at three random points. Part of the collected samples was kept immediately in moisture tins for the determination of soil moisture, and the remaining samples were pooled to form one composite sample. The samples were air-dried at room temperature for one week and then dried in an oven at $65{ }^{\circ} \mathrm{C}$ and sieved using a 2-mm sieve. The soil moisture was determined by the weight-loss method, based on three replicas per each quadrat. Soil texture was determined according to Bouyoucos [31]. Soil water paste, in the ratio of 1:5, was prepared, and immediately the soil electrical conductivity (EC) and $\mathrm{pH}$ were measured [32]. Carbonates were estimated by titration using $0.1 \mathrm{~N} \mathrm{HCl}$ [33], and $\mathrm{SO}_{4}$ content was determined gravimetrically according to Piper [34], using barium chloride. The soluble cations (Na and $\mathrm{K}$ ) were measured using flame photometry (PHF 80B Biologie Spectrophotometer), while $\mathrm{Ca}$ and $\mathrm{Mg}$ were estimated using the atomic absorption spectrometer (A Perkin-Elmer, Model 2380, Waltham, MA, USA) according to Allen, et al. [35]. 


\subsection{Data Analysis}

To recognize the plant communities in the study area, the data of the importance values, derived from density and cover, of the plant species within 15 stands were subjected to two-way indicator species analysis (TWINSPAN) for classification, and detrended correspondence analysis (DCA), for ordination [36-38]. The soil variables for the identified communities were subjected to one-way ANOVA and the mean values were separated based on Duncan's test at 0.05 probability level to examine the significant difference among plant communities. In order to detect the relationship between the dominant and important plant species of the four identified communities on one hand and soil variable data, on the other hand, canonical correspondence analysis (CCA) according to Ter Braak and Smilauer [39] was conducted.

\section{Results}

\subsection{Vegetation Composition}

The floristic survey of the study area revealed the presence of 111 plant species; 51 perennials and 60 annuals (Table S2). These plant species belong to 39 families, where the most represented families were Asteraceae, Poaceae, Brassicaceae, Caryophyllaceae, and Papilionaceae, which represent $55.4 \%$ of the total species (Figure 2). The therophytes were the dominant life form, representing $46.9 \%$ of the total number of species (Figure 2).

a)

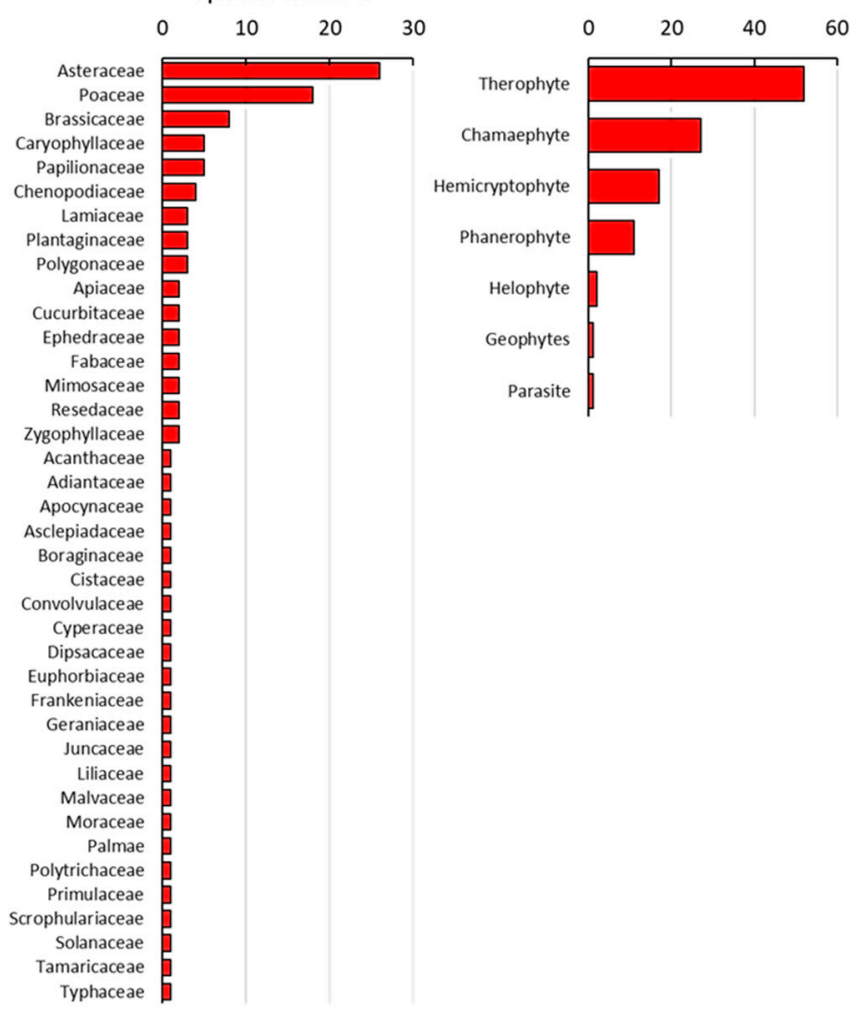

Figure 2. Plant families of the recorded plant species (a) and the life forms according to Raunkiaer's classification (b).

The application of cluster analysis (TWINSPAN) to the data of importance values of each species, based on the relative cover and density, led to the recognition of four plant communities (Figure 3 and Table 1). These communities were (A) Phragmites australisTamarix nilotica community, (B) Zygophyllum coccineum-Acacia gerrardii community, (C) Lycium shawii-Zygophyllum coccineum community, and (D) Rhazya stricta community. 


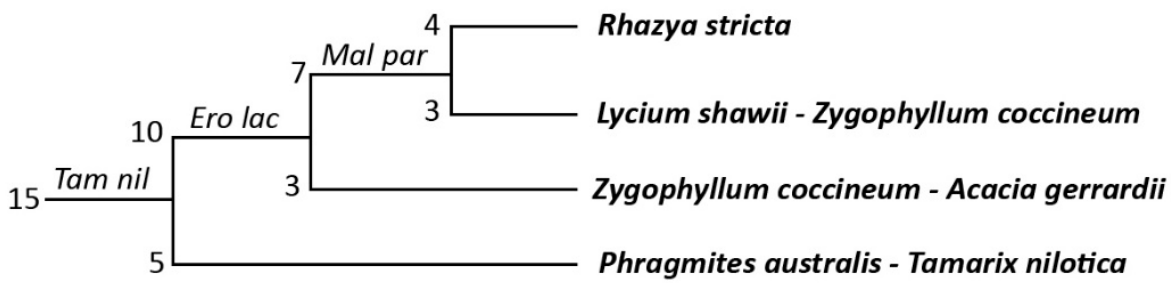

Figure 3. TWINSPAN dendrogram of different sampled stands based on the importance values of the recorded perennial species $(n=49)$. Indicator species names are abbreviated to the first three letters of both genus and species. Mal par: Malva parviflora, Ero lac: Erodium laciniatum, and Tam nil: Tamarix nilotica.

Table 1. Plant communities of the perennial species recorded in the study area.

\begin{tabular}{|c|c|c|c|c|c|}
\hline & \multirow{2}{*}{ Parameter } & \multicolumn{4}{|c|}{ Plant Community } \\
\hline & & A & B & C & D \\
\hline & Stand no. & 5 & 3 & 3 & 4 \\
\hline & Species no. & 40 & 21 & 21 & 20 \\
\hline & Simpson index & 0.95 & 0.91 & 0.94 & 0.92 \\
\hline & Shannon-evenness & 0.81 & 0.76 & 0.86 & 0.76 \\
\hline No. & Plant species & \multicolumn{4}{|c|}{ Average of importance value } \\
\hline 1 & Acacia ehrenbergiana Hayne & $7.20 \pm 1.38$ * & $21.25 \pm 5.88$ & $8.16 \pm 3.82$ & $17.27 \pm 3.05$ \\
\hline 2 & Acacia gerrardii Benth. & $4.99 \pm 1.90$ & $30.67 \pm 10.25$ & $16.49 \pm 3.13$ & $5.09 \pm 2.24$ \\
\hline 3 & Acacia tortilis (Forssk.) Hayne & $5.88 \pm 2.55$ & - & $12.88 \pm 6.02$ & $18.65 \pm 3.45$ \\
\hline 4 & Adiantum capillus-veneris L. & $4.42 \pm 2.72$ & - & - & - \\
\hline 5 & Aeluropus lagopoides (L.) Thwaites & $22.60 \pm 7.78$ & - & - & - \\
\hline 6 & Alhagi graecorum Boiss. & $1.34 \pm 0.82$ & $1.29 \pm 0.67$ & - & $1.55 \pm 0.68$ \\
\hline 7 & Artemisia monosperma Delile & - & $5.90 \pm 1.54$ & - & \\
\hline 8 & Artemisia sieberi Besser & $1.17 \pm 0.72$ & - & $6.98 \pm 1.73$ & $22.50 \pm 5.54$ \\
\hline 9 & Artemisia pycnocephala (Less.) DC. & $0.69 \pm 0.43$ & - & - & - \\
\hline 10 & Astragalus spinosus (Forssk.) Muschl. & - & - & $6.07 \pm 1.69$ & $10.05 \pm 2.77$ \\
\hline 11 & Atriplex leucoclada Boiss. & $1.90 \pm 0.81$ & - & - & - \\
\hline 12 & Blepharis ciliaris (L.) B.L.Burtt & $0.69 \pm 0.43$ & - & - & $3.26 \pm 0.84$ \\
\hline 13 & Cenchrus ciliaris L. & $3.97 \pm 1.02$ & - & $5.00 \pm 2.34$ & - \\
\hline 14 & Cucumis prophetarum L. & $0.56 \pm 0.35$ & - & - & - \\
\hline 15 & Citrullus colocynthis (L.) Schrad. & - & - & $1.90 \pm 0.89$ & - \\
\hline 16 & Cynodon dactylon (L.) Pers. & $3.14 \pm 1.34$ & $12.98 \pm 3.368$ & $11.00 \pm 2.59$ & - \\
\hline 17 & Cymbopogon commutatus (Steud.) Stapf & $2.27 \pm 1.40$ & $9.80 \pm 2.93$ & - & $3.97 \pm 1.74$ \\
\hline 18 & Ephedra foliata Boiss. ex C.A.Mey. & $0.56 \pm 0.35$ & - & - & - \\
\hline 19 & Ephedra ciliata Fisch. \& C.A.Mey. & - & $3.44 \pm 0.96$ & $7.22 \pm 3.37$ & - \\
\hline 20 & Fagonia bruguieri DC. & $1.92 \pm 0.49$ & $1.70 \pm 0.89$ & - & $2.19 \pm 0.97$ \\
\hline 21 & Farsetia aegyptia Turra & $1.26 \pm 0.48$ & - & $1.90 \pm 0.89$ & $1.55 \pm 0.68$ \\
\hline 22 & Ficus salicifolia Vahl & $2.05 \pm 1.26$ & - & - & - \\
\hline 23 & Gymnocarpos decandrus Forssk. & $1.84 \pm 0.47$ & - & - & $1.55 \pm 0.68$ \\
\hline 24 & Haloxylon salicornicum (Moq.) Bunge ex Boiss. & $2.67 \pm 1.64$ & - & - & - \\
\hline 25 & Helianthemum lippii (L.) Dum. Cours. & $1.28 \pm 0.48$ & $2.91 \pm 0.76$ & $7.27 \pm 0.30$ & $1.81 \pm$ \\
\hline 26 & Hyparrhenia hirta (L.) Stapf & $3.16 \pm 1.37$ & $3.61 \pm 0.97$ & $5.61 \pm 1.31$ & - \\
\hline 27 & Juncus rigidus Desf. & $22.31 \pm 3.60$ & - & - & - \\
\hline 28 & Lycium shawii Roem. \& Schult. & $5.77 \pm 0.97$ & $3.91 \pm 2.03$ & $31.22 \pm 8.19$ & $22.46 \pm 9.88$ \\
\hline 29 & Moricandia sinaica (Boiss.) Boiss. & - & $11.37 \pm 3.76$ & $1.84 \pm 0.86$ & $1.45 \pm 0.64$ \\
\hline 30 & Ochradenus baccatus Delile & $4.82 \pm 0.81$ & $1.35 \pm 0.70$ & $11.62 \pm 1.49$ & $6.00 \pm 1.52$ \\
\hline 31 & Panicum turgidum Forssk. & $1.32 \pm 0.81$ & $3.12 \pm 1.63$ & - & - \\
\hline 32 & Pennisetum divisum (Forssk. ex J.F.Gmel.) Henrard & - & - & - & $9.38 \pm 4.12$ \\
\hline 33 & Pergularia tomentosa L. & $0.56 \pm 0.35$ & - & $1.90 \pm 0.89$ & - \\
\hline 34 & Phoenix dactylifera L. & $3.25 \pm 1.23$ & - & - & - \\
\hline 35 & Phragmites australis (Cav.) Trin. ex Steud. & $29.97 \pm 9.78$ & - & - & - \\
\hline 36 & Polygonum aviculare L. & $0.56 \pm 0.35$ & - & - & - \\
\hline 37 & Prosopis farcta (Banks \& Sol.) J.F.Macbr. & $1.32 \pm 0.81$ & - & - & - \\
\hline 38 & Pulicaria undulata (L.) Kostel. & $0.91 \pm 0.56$ & $3.26 \pm 0.85$ & $2.83 \pm 1.32$ & $1.36 \pm 0.60$ \\
\hline 39 & Reseda muricata C.Presl & - & - & $4.23 \pm 1.01$ & - \\
\hline 40 & Rhanterium epapposum Oliv. & $2.69 \pm 1.10$ & $2.09 \pm 1.09$ & - & - \\
\hline
\end{tabular}


Table 1. Cont.

\begin{tabular}{|c|c|c|c|c|c|}
\hline & \multirow{2}{*}{ Parameter } & \multicolumn{4}{|c|}{ Plant Community } \\
\hline & & A & B & $\mathrm{C}$ & $\mathbf{D}$ \\
\hline & Stand no. & 5 & 3 & 3 & 4 \\
\hline & Species no. & 40 & 21 & 21 & 20 \\
\hline & Simpson index & 0.95 & 0.91 & 0.94 & 0.92 \\
\hline & Shannon-evenness & 0.81 & 0.76 & 0.86 & 0.76 \\
\hline No. & Plant species & \multicolumn{4}{|c|}{ Average of importance value } \\
\hline 41 & Rhazya stricta Decne. & - & $14.81 \pm 3.89$ & $21.84 \pm 7.19$ & $47.34 \pm 5.06$ \\
\hline 42 & Scirpoides holoschoenus (L.) Soják & $1.18 \pm 0.72$ & - & - & - \\
\hline 43 & Scrophularia deserti Delile & - & $2.09 \pm 1.09$ & - & - \\
\hline 44 & Stipagrostis plumosa Munro ex T.Anderson & - & $3.30 \pm 1.72$ & - & - \\
\hline 45 & Tamarix nilotica (Ehrenb.) Bunge & $27.71 \pm 4.93$ & - & - & - \\
\hline 46 & Teucrium polium L. & $0.59 \pm 0.36$ & - & - & - \\
\hline 47 & Typha domingensis Pers. & $5.49 \pm 3.37$ & - & - & - \\
\hline 48 & Zilla spinosa (L.) Prantl & $0.56 \pm 0.35$ & $1.70 \pm 0.89$ & $4.62 \pm 1.15$ & $4.22 \pm 1.09$ \\
\hline 49 & Zygophyllum coccineum $\mathrm{L}$. & $15.40 \pm 3.46$ & $59.41 \pm 13.27$ & $29.41 \pm 0.71$ & $18.36 \pm 5.63$ \\
\hline
\end{tabular}

* values are average of the importance values of species based on the relative cover and density \pm standard error. A: Phragmites australisTamarix nilotica community, B: Zygophyllum coccineum—Acacia gerrardii community, C: Lycium shawii-Zygophyllum coccineum community, and D: Rhazya stricta community.

The community of Phragmites australis - Tamarix nilotica colonizes the wadi's head, where the soil moisture and salinity were high, and it was the most diverse community (40 species). It attained the highest richness (Simpson diversity index $=0.95$ ). Moreover, other important hydrophytic and halophytic species were recorded such as Aeluropus lagopoides and Juncus rigidus (Table 1). The Zygophyllum coccineum-Acacia gerrardii community inhabits the first section of the wadi, where the moisture content decreased. This community attained the Simpson diversity index of 0.91 and Shannon-evenness of 0.76 . The other important species in this community were Acacia ehrenbergiana, Rhazya stricta, and Cynodon dactylon.

The Lycium shawii-Zygophyllum coccineum community is represented the central region of the wadi, where the water content is very low. This community attained the highest evenness (Shannon-evenness of 0.76) and richness (Simpson index of 0.95). Rhazya stricta, Acacia tortilis, Cynodon dactylon, and Ochradenus baccatus attained the highest importance values in this community. Finally, Rhazya stricta community colonized the last portion of the wadi, where it is characterized by sandy habitat, and it contained 20 species. The Simpson index of this community was 0.92 , while the Shannon-evenness was 0.76 . The other important species of this community were Lycium shawii, Artemisia sieberi, Zygophyllum cocineum, Acacia tortilis, and Acacia ehrenbergiana (Table 1).

\subsection{Vegetation-Soil Relationship}

The soil analysis of the studied stands revealed significant variation among the identified communities (Table 2). Soil salinity, moisture, $\mathrm{CO}_{3}, \mathrm{Cl}_{1} \mathrm{SO}_{4}, \mathrm{Ca}, \mathrm{Mg}$, and Na contents showed a highly significant $(p<0.05)$ difference among the plant communities. However, sand, silt, and K contents did not show a significant difference. The community of Phragmites australis-Tamarix nilotica attained the highest soil moisture, salinity, $\mathrm{Cl}, \mathrm{SO}_{4}, \mathrm{Na}, \mathrm{Ca}$, and Mg. However, the community of Lycium shawii-Zygophyllum coccineum exhibited the lowest content of moisture, sand, $\mathrm{SO}_{4}, \mathrm{~K}, \mathrm{Ca}$, and $\mathrm{Mg}$. The lowest salinity content was recorded for Rhazya stricta community, which inhabits the wadi tail. 
Table 2. Soil characteristics of the four determined plant communities in the study area.

\begin{tabular}{|c|c|c|c|c|c|c|}
\hline \multirow{2}{*}{ Parameters } & \multicolumn{4}{|c|}{ Plant Community } & \multirow{2}{*}{$F$ Value } & \multirow{2}{*}{$p$ Value } \\
\hline & A & B & $\mathrm{C}$ & D & & \\
\hline Clay (\%) & $7.01 \pm 1.46 * \mathrm{AB}$ & $5.34 \pm 0.44^{\mathrm{B}}$ & $11.39 \pm 1.93^{\mathrm{A}}$ & $6.54 \pm 1.14 \mathrm{AB}$ & 3.788 & $0.0213^{*}$ \\
\hline Silt (\%) & $6.86 \pm 1.25^{\mathrm{A}}$ & $5.66 \pm 0.66^{\mathrm{A}}$ & $9.51 \pm 2.17^{\mathrm{A}}$ & $7.31 \pm 1.19^{\mathrm{A}}$ & 1.273 & 0.3028 \\
\hline Sand $(\%)$ & $86.13 \pm 2.60 \mathrm{AB}$ & $89.00 \pm 0.57^{\mathrm{A}}$ & $79.10 \pm 3.95^{\mathrm{B}}$ & $86.15 \pm 1.86 \mathrm{AB}$ & 2.721 & 0.0633 \\
\hline $\mathrm{pH}$ & $8.30 \pm 0.10^{\mathrm{A}}$ & $8.16 \pm 0.15^{\mathrm{A}}$ & $8.45 \pm 0.08^{\mathrm{A}}$ & $8.22 \pm 0.12 \mathrm{~A}$ & 1.093 & 0.3683 \\
\hline $\mathrm{EC}\left(\mathrm{dS} \mathrm{m}^{-1}\right)$ & $2.50 \pm 0.15^{\mathrm{A}}$ & $0.85 \pm 0.23^{\mathrm{B}}$ & $0.42 \pm 0.02^{\mathrm{BC}}$ & $0.30 \pm 0.05^{\mathrm{C}}$ & 52.000 & $<0.0001^{* * *}$ \\
\hline $\mathrm{CO}_{3}(\%)$ & $0.69 \pm 0.08^{\mathrm{B}}$ & $1.35 \pm 0.18^{\mathrm{A}}$ & $1.20 \pm 0.08 \mathrm{~A}$ & $1.43 \pm 0.15^{\mathrm{A}}$ & 6.366 & $0.0020 * *$ \\
\hline $\mathrm{Cl}(\mathrm{meq} / \mathrm{L})$ & $4.54 \pm 0.74 \mathrm{~A}$ & $2.15 \pm 0.38^{\mathrm{B}}$ & $1.38 \pm 0.44^{\text {В }}$ & $0.60 \pm 0.07^{\text {B }}$ & 13.034 & $<0.0001^{* * *}$ \\
\hline $\mathrm{SO}_{4}(\mathrm{meq} / \mathrm{L})$ & $23.91 \pm 2.65^{\mathrm{A}}$ & $2.49 \pm 0.51^{\text {В }}$ & $0.69 \pm 0.09^{\mathrm{B}}$ & $1.06 \pm 0.21^{\text {В }}$ & 69.373 & $<0.0001^{* * *}$ \\
\hline $\mathrm{Ca}(\mathrm{meq} / \mathrm{L})$ & $16.90 \pm 2.43^{\mathrm{A}}$ & $2.79 \pm 0.53^{\text {В }}$ & $1.44 \pm 0.20^{\mathrm{B}}$ & $2.61 \pm 0.34^{B}$ & 33.846 & $<0.0001^{* * *}$ \\
\hline $\mathrm{Mg}(\mathrm{meq} / \mathrm{L})$ & $8.15 \pm 1.39^{\mathrm{A}}$ & $2.28 \pm 0.73^{\mathrm{B}}$ & $0.69 \pm 0.09^{\mathrm{B}}$ & $1.51 \pm 0.43^{\mathrm{B}}$ & 17.343 & $<0.0001^{* * *}$ \\
\hline $\mathrm{Na}(\mathrm{meq} / \mathrm{L})$ & $4.59 \pm 0.99^{\mathrm{A}}$ & $1.13 \pm 0.54^{\mathrm{B}}$ & $0.42 \pm 0.16^{\mathrm{B}}$ & $0.31 \pm 0.07^{\mathrm{B}}$ & 12.500 & $<0.0001^{* * *}$ \\
\hline $\mathrm{K}(\mathrm{meq} / \mathrm{L})$ & $0.38 \pm 0.08^{\mathrm{A}}$ & $0.40 \pm 0.13^{\mathrm{A}}$ & $0.20 \pm 0.03^{\mathrm{A}}$ & $0.35 \pm 0.03^{\mathrm{A}}$ & 1.288 & 0.2978 \\
\hline Moisture (\%) & $18.76 \pm 2.70^{\mathrm{A}}$ & $0.97 \pm 0.12^{\mathrm{B}}$ & $0.65 \pm 0.09^{\mathrm{B}}$ & $0.94 \pm 0.14^{\text {В }}$ & 43.734 & $<0.0001^{* * *}$ \\
\hline
\end{tabular}

* values are average \pm standard error. EC: electrical conductivity. Within each row, means followed by the same superscript letter are not significantly different at the 0.05 level using Tukey's HSD test. ${ }^{* * *} p<0.001,{ }^{* *} p<0.01$ ${ }^{*} p<0.05$. A: Phragmites australis-Tamarix nilotica community, B: Zygophyllum coccineum-Acacia gerrardii community, C: Lycium shawii-Zygophyllum coccineum community, and D: Rhazya stricta community.

The correlation between the environmental (edaphic) factors and CCA axes showed that plant species along the first axis were positively correlated with moisture, salinity, $\mathrm{Cl}$, $\mathrm{SO}_{4}, \mathrm{Na}, \mathrm{Ca}$, and $\mathrm{Mg}$ (Table 3). The CCA revealed that Phragmites australis-Tamarix nilotica community was segregated on the right side of the CCA biplot, and it was correlated to the soil moisture, salinity, $\mathrm{Cl}, \mathrm{SO}_{4}, \mathrm{Na}, \mathrm{Ca}$, and $\mathrm{Mg}$. Correlation analysis between the soil variables and dominant and important plant species is shown in Figure 4. Aeluropus lagopoides, Juncus rigidus, Phragmites australis, and Tamarix nilotica showed a positive correlation with salinity, $\mathrm{Cl}, \mathrm{SO}_{4}, \mathrm{Na}, \mathrm{K}, \mathrm{Ca}$, and $\mathrm{Mg}$. On the other hand, the invasive plant Rhazya stricta showed a negative correlation with all these soil parameters.

Table 3. Inter-set correlations between environmental variables and site scores with CCA axes.

\begin{tabular}{cccc}
\hline Variable & Axis $\mathbf{1}$ & Axis $\mathbf{2}$ & Axis 3 \\
\hline Eigenvalues & 0.631 & 0.369 & 0.288 \\
Percentage & 28.513 & 16.684 & 13.016 \\
Cum. Percentage & 28.513 & 45.197 & 58.213 \\
Species-environmental & 0.999 & 0.987 & 0.994 \\
correlations & & & 0.111 \\
Clay & -0.190 & 0.200 & -0.153 \\
$\mathrm{Silt}$ & -0.203 & 0.257 & 0.028 \\
$\mathrm{Sand}$ & 0.207 & -0.241 & 0.083 \\
$\mathrm{pH}$ & 0.271 & 0.610 & 0.301 \\
$\mathrm{EC}$ & 0.867 & -0.252 & 0.185 \\
$\mathrm{CO}$ & -0.813 & 0.070 & 0.121 \\
$\mathrm{Cl}$ & 0.865 & -0.220 & -0.002 \\
$\mathrm{SO}_{4}$ & 0.917 & -0.277 & -0.099 \\
$\mathrm{Ca}$ & 0.814 & -0.384 & 0.019 \\
$\mathrm{Mg}$ & 0.815 & -0.505 & 0.053 \\
$\mathrm{Na}$ & 0.826 & -0.120 & 0.354 \\
$\mathrm{~K}$ & 0.154 & -0.137 & -0.036 \\
\hline $\mathrm{Moisture}$ & 0.940 & 0.183 &
\end{tabular}




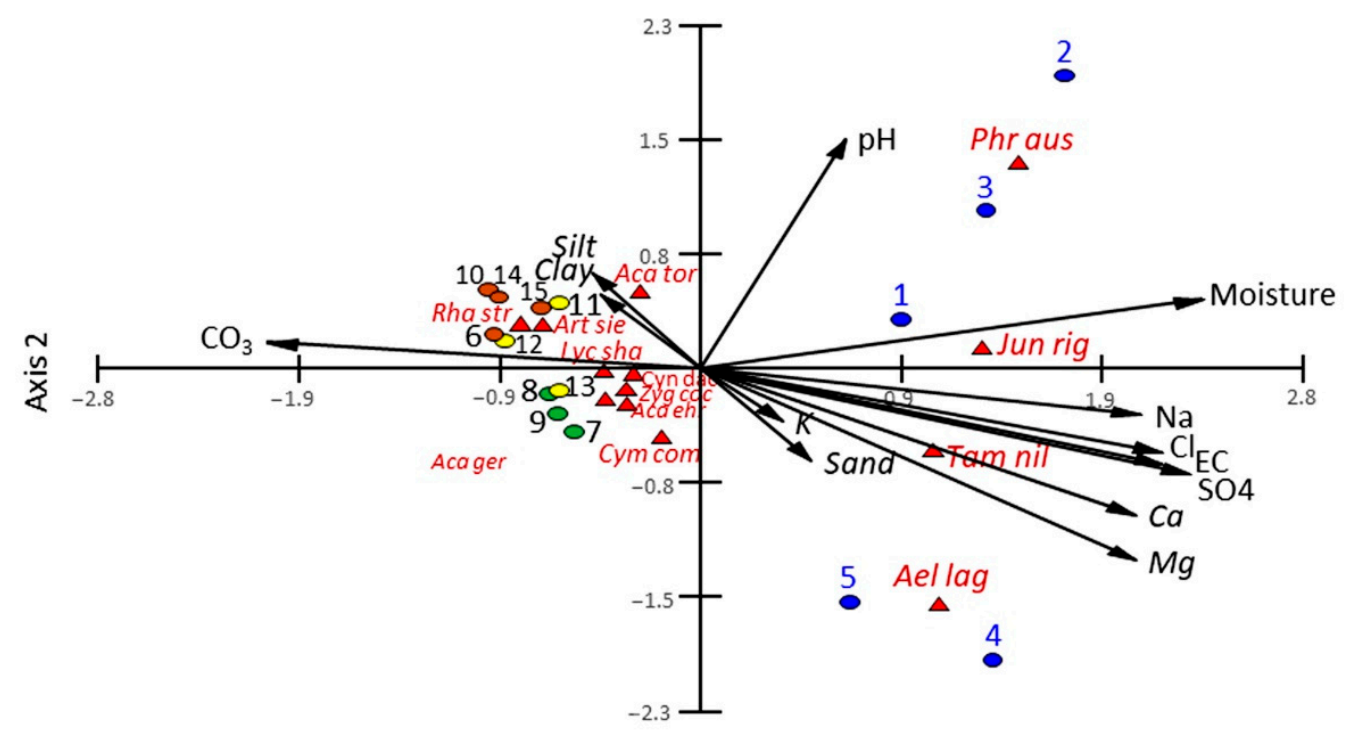

Axis 1

Figure 4. CCA ordination bi-plot between the soil variables and the dominant and important plant species of the four identified communities. Plant species names are abbreviated to the first three letters of both genus and species. Acacia ehrenbergiana, Acacia gerardii, Acacia tortilis, Aeluropus lagopoides, Artemisia sieberi, Cynodon dactylon, Cymbopogon commutatus, Phragmites australis, Juncus rigidus, Lycium shawii, Rhazya stricta, Tamarix nilotica, and Zygophyllum coccineum, and EC: electrical conductivity.

\section{Discussion}

Although, the climate in Saudi Arabia is arid, there are various wetlands habitats such as sabkha, mangrove, and wadi systems [1]. These habitats play a vital role in the conservation of biodiversity as they support a unique assemblage of plant communities. Wadi systems are considered the most distinguishable landforms in deserts. Wadis are usually located on gentle slopes and have braided stream patterns due to water deficiency and abundance of sediments [40].

The floristic analysis revealed the predominance of therophytes reflecting the prevailing desert environment, where annuals flourished during the rainy season. These annual plants have high reproductive capacity phenotypic plasticity enabling them to thrive in the desert environment [41]. The preponderance of Asteraceae, Poaceae, and Brassicaceae in the present study was in harmony with other previous studies in different wadis [42-47]. Asteraceae and Poaceae families are the largest families worldwide, particularly in arid and semi-arid regions $[48,49]$.

Four plant communities were identified via the classification of stands. Among these communities, Phragmites australis-Tamarix nilotica community was the most diverse and has the highest Simpson diversity index. This community colonizes the head of the wadi, where it receives the highest amount of water. It is worth mentioning here that the road construction that cut the wadi head led to trapping of water that percolates toward the wadi stream. This makes the head of the wadi mostly moist $(17.76 \%)$ year-round, and we consider that this is the reason for high plant diversity in that location. In this community, hydrophytes were observed such as Phragmites australis, Juncus rigidus, Tamarix nilotica, and Aeluropus lagopoides. This community colonizes the head of the wadi, where it receives a high amount of water. Also, the higher soil water content of this community enabled maidenhair fern; Adiantum capillus-veneris to inhabit the shaded places of this habitat. Very few studies in the Riyadh region or other regions having similar climatic conditions indicated the presence of A. capillus-veneris [50-52] and Ficus salicifolia [53]. The presence of those two rare wetland species in the study area necessitates an urgent biodiversity conservation action. 
The soil analysis and the CCA revealed that the Phragmites australis-Tamarix nilotica community was affected by the content of soil moisture, salinity, $\mathrm{Cl}, \mathrm{SO}_{4}, \mathrm{Na}, \mathrm{Ca}$, and $\mathrm{Mg}$. Salinity is one of the most important factors affecting plant communities' assemblage [54,55]. Water is one of the crucial factors that affect the plant community structure, dynamics, and composition in arid regions $[17,56]$. The water of the desert ecosystem includes precipitation, sand adsorbed water, surface runoff, air-water, and groundwater [57]. Due to the higher rate of evapotranspiration in the desert ecosystem, salinity often increases, hindering plant water uptake [58]. In this context, salinity is one of the most important factors affecting plant communities' assemblage [54,55]. A study by Gong, et al. [55] reported that aridity and salinity control plant community structure rather than soil fertility. In the present study, the community of Phragmites australis-Tamarix nilotica contained important salt-tolerant species, which reflect saline environmental conditions, for example, Juncus rigidus, Tamarix nilotica, and Aeluropus lagopoides. These species are considered bioindicators for salinity [59].

Along the wadi, the gradient of soil moisture content and salinity decreased. Therefore, the plant communities changed dramatically, where the Zygophyllum coccineum-Acacia gerardii and Lycium shawii-Zygophyllum cocineum communities colonized the central region of the wadi. In these communities, the Acacia trees (Acacia gerardii, Acacia ehrenbergiana, and Acacia tortilis) colonize this region forming a woodland community with association of other xerophytes such as Lycium shawii, Ochradenus baccatus, Zygophyllum cocineum, Rhazya stricta, and Cynodon dactylon. These plants are the common plants in various wadis in desert habitats of Saudi Arabia [27,28,60-62].

The invasive plant Rhazya stricta forms the last community in the wadi, where the diversity of species becomes low. This community showed a negative correlation with most of the soil parameters (salinity, $\mathrm{Cl}, \mathrm{SO}_{4}, \mathrm{Na}, \mathrm{K}, \mathrm{Ca}$, and $\mathrm{Mg}$ ), which reflects that this weed can grow in poor soil. The invasive plants have higher colonization in nutrientpoor environments compared to native ones [63,64]. It is worth mentioning here that we observed anthropogenic interference, particularly the grazing, at the end of the wadi, and we think that the presence of some annual species like Malva parviflora is a result of this factor. This species was possibly introduced as a result of supplementary feeds provided to livestock in impermanent paddocks.

\section{Conclusions}

The floristic and vegetation analysis of the Wadi Hargan, Riyadh, Saudi Arabia, showed distinct four plant communities along the wadi. These communities showed substantial variation in their structure and assemblage. The content of salinity, moisture, $\mathrm{CO}_{3}, \mathrm{Cl}, \mathrm{SO}_{4}, \mathrm{Ca}, \mathrm{Mg}$, and $\mathrm{Na}$ were the soil factors that affect the distribution and structure of these communities. Moreover, it can be concluded that soil moisture and salinity factors were the key driving forces for plant community structure in the studied wadi. The wadi is subjected to moderate grazing, mainly by camels; thereby, the invasive plant Rhazya stricta was dominant in the central region of the wadi. Also, human interference was observed at the end of the wadi, where some weeds sprouted such as Malva parviflora. The wetlands are considered hotspots for plant biodiversity; therefore, we recommend including the studied wadi under the conservation strategy to protect its natural vegetation from overgrazing and human interference.

Supplementary Materials: The following are available online at https:/ / www.mdpi.com/article/ 10.3390/d13110587/s1, Table S1: The coordinates and elevation of the studied stands along Wadi Hargan, Saudi Arabia, Table S2: The floristic analysis of the recorded plant species in the study area.

Author Contributions: Conceptualization, A.M.A.-E., A.M.A. and B.M.D.; Formal analysis, A.M.A.E., A.M.A., J.A.M. and B.M.D.; Investigation, A.M.A.-E., A.M.A., S.L.A.-R. and B.M.D.; Methodology, A.M.A.-E., A.M.A. and B.M.D.; Resources, A.M.A.-E., S.L.A.-R. and A.M.A.; Writing-original draft, A.M.A.-E., A.M.A. and B.M.D.; Writing-review \& editing, A.M.A.-E., A.M.A., S.L.A.-R., J.A.M. and B.M.D. All authors have read and agreed to the published version of the manuscript. 
Funding: This research was supported by the Deanship of Scientific Research at King Saud University through research group No (RG-1441-302).

Institutional Review Board Statement: Not applicable.

Informed Consent Statement: Not applicable.

Data Availability Statement: Not available.

Acknowledgments: The authors extend their appreciation to the Deanship of Scientific Research at King Saud University for supporting this work through research group No (RG-1441-302).

Conflicts of Interest: The authors declare no conflict of interest.

\section{References}

1. Al-Obaid, S.; Samraoui, B.; Thomas, J.; El-Serehy, H.A.; Alfarhan, A.H.; Schneider, W.; O'connell, M. An overview of wetlands of Saudi Arabia: Values, threats, and perspectives. Ambio 2017, 46, 98-108. [CrossRef]

2. Hunter, M.L., Jr.; Acuña, V.; Bauer, D.M.; Bell, K.P.; Calhoun, A.J.; Felipe-Lucia, M.R.; Fitzsimons, J.A.; González, E.; Kinnison, M.; Lindenmayer, D. Conserving small natural features with large ecological roles: A synthetic overview. Biol. Conserv. 2017, 211, 88-95. [CrossRef]

3. Springer, K.B.; Manker, C.R.; Pigati, J.S. Dynamic response of desert wetlands to abrupt climate change. Proc. Natl. Acad. Sci. USA 2015, 112, 14522-14526. [CrossRef] [PubMed]

4. Patten, D.T.; Rouse, L.; Stromberg, J.C. Isolated spring wetlands in the Great Basin and Mojave Deserts, USA: Potential response of vegetation to groundwater withdrawal. Environ. Manag. 2008, 41, 398-413. [CrossRef]

5. Villa, J.A.; Bernal, B. Carbon sequestration in wetlands, from science to practice: An overview of the biogeochemical process, measurement methods, and policy framework. Ecol. Eng. 2018, 114, 115-128. [CrossRef]

6. Sutton-Grier, A.E.; Sandifer, P.A. Conservation of wetlands and other coastal ecosystems: A commentary on their value to protect biodiversity, reduce disaster impacts, and promote human health and well-being. Wetlands 2019, 39, 1295-1302. [CrossRef]

7. Orimoloye, I.R.; Kalumba, A.M.; Mazinyo, S.P.; Nel, W. Geospatial analysis of wetland dynamics: Wetland depletion and biodiversity conservation of Isimangaliso Wetland, South Africa. J. King Saud Univ. Sci. 2020, 32, 90-96. [CrossRef]

8. McKinstry, M.C.; Hubert, W.A.; Anderson, S.H. Wetland and Riparian Areas of the Intermountain West: Ecology and Management; University of Texas Press: Austin, TX, USA, 2004; Volume 4.

9. Williams, W.D. Biodiversity in temporary wetlands of dryland regions. Int. Ver. Für Theor. Und Angew. Limnol. Verh. 2000, 27, 141-144. [CrossRef]

10. Noby, K.; Kingma, S.; Heitkönig, I.M.A.; Bulte, E.H.; Naguib, M. Smelly wetlands in the Sahara: Role of sewage ponds in bird migration across Egypt. In Proceedings of Wias Annual Conference; Wageningen University: Lunteren, The Netherlands, $2020 ;$ p. 70.

11. Tinley, K. Survey of Saudi Arabian Wetlands; IUCN/NCWCD Report; General Intelligence Presidency: Riyadh, Saudi Arabia, 1994.

12. Schenk, H.J.; Holzapfel, C.; Hamilton, J.G.; Mahall, B.E. Spatial ecology of a small desert shrub on adjacent geological substrates. J. Ecol. 2003, 91, 383-395. [CrossRef]

13. Zhang, D.-M.; Zhao, W.-Z.; Zhang, G.-F. Soil moisture and salt ionic composition effects on species distribution and diversity in semiarid inland saline habitats, northwestern China. Ecol. Res. 2018, 33, 505-515. [CrossRef]

14. Peters, D.P.; Yao, J.; Sala, O.E.; Anderson, J.P. Directional climate change and potential reversal of desertification in arid and semiarid ecosystems. Glob. Chang. Biol. 2012, 18, 151-163. [CrossRef]

15. Deng, L.; Wang, K.; Li, J.; Zhao, G.; Shangguan, Z. Effect of soil moisture and atmospheric humidity on both plant productivity and diversity of native grasslands across the Loess Plateau, China. Ecol. Eng. 2016, 94, 525-531. [CrossRef]

16. Li, W.-Q.; Xiao-Jing, L.; Khan, M.A.; Gul, B. Relationship between soil characteristics and halophytic vegetation in coastal region of North China. Pak. J. Bot. 2008, 40, 1081-1090.

17. Xi, H.; Feng, Q.; Zhang, L.; Si, J.; Chang, Z.; Yu, T.; Guo, R. Effects of water and salinity on plant species composition and community succession in Ejina Desert Oasis, northwest China. Environ. Earth Sci. 2016, 75, 138. [CrossRef]

18. Mętrak, M.; Chachulski, Ł.; Navruzshoev, D.; Pawlikowski, P.; Rojan, E.; Sulwiński, M.; Suska-Malawska, M. Nature's patchwork: How water sources and soil salinity determine the distribution and structure of halophytic plant communities in arid environments of the Eastern Pamir. PLoS ONE 2017, 12, e0174496. [CrossRef] [PubMed]

19. Chaieb, G.; Abdelly, C.; Michalet, R. Interactive effects of climate and topography on soil salinity and vegetation zonation in North-African continental saline depressions. J. Veg. Sci. 2019, 30, 312-321. [CrossRef]

20. Pringle, C.M. Threats to US public lands from cumulative hydrologic alterations outside of their boundaries. Ecol. Appl. 2000, 10, 971-989. [CrossRef]

21. Pringle, C.M. Hydrologic connectivity and the management of biological reserves: A global perspective. Ecol. Appl. 2001, 11, 981-998. [CrossRef]

22. Al-Amro, A.; El-Sheikh, M.; El-Sheikh, A. Vegetation analysis of some wetland habitats in central region of Saudi Arabia. Appl. Ecol. Environ. Res. 2018, 16, 3255-3269. [CrossRef] 
23. Galal, T.M.; Al-Yasi, H.M.; Fadl, M.A. Vegetation zonation along the desert-wetland ecosystem of Taif Highland, Saudi Arabia. Saudi J. Biol. Sci. 2021, 28, 3374-3383. [CrossRef] [PubMed]

24. Vincent, P. Saudi Arabia: An Environmental Overview; Taylor \& Francis: Leiden, The Netherlands, 2008.

25. Bonham, C.D. Measurements for Terrestrial Vegetation; John Wiley \& Sons: New York, NY, USA, 2013.

26. Mueller-Dombois, D.; Ellenberg, H. Aims and Methods of Vegetation Ecology; Wiley and Sons: New York, NY, USA, 1974.

27. Collenette, S. Wildflowers of Saudi Arabia; National Commission for Wildlife Conservation and Development (NCWCD): Riyadh, Saudi Arabia, 1999.

28. Chaudhary, S.A. Flora of the Kingdom of Saudi Arabia; Ministry of Agriculture and Water: Riyadh, Saudi Arabia, 1999.

29. Raunkiaer, C. Plant Life Forms; Clarendon Press: Oxford, UK, 1937.

30. Zohary, M. Geobotanical Foundations of the Middle East; Gustav Fischer Verlag: Stuttgart, Germany, 1973.

31. Bouyoucos, G.J. Hydrometer method improved for making particle size analyses of soils. Agron. J. 1962, 54, 464-465. [CrossRef]

32. Rowell, D. Soil Science: Methods and Applications; Longman Group: Essex, UK, 1994.

33. Pierce, W.C.; Haenisch, E.L.; Sawyer, D.T. Quantitative Analysis; Wiley Toppen: Tokyo, Japan, 1958.

34. Piper, C.S. Soil and Plant Analysis; Interscience Publishers Inc.: New York, NY, USA, 1947.

35. Allen, S.E.; Grimshaw, H.; Parkinson, J.A.; Quarmby, C. Chemical Analysis of Ecological Materials; Blackwell Scientific Publications: Oxford, UK, 1974.

36. Hill, M.O. Decorana-A FORTRAN Program for Detrended Correspondence Analysis and Reciprocal Averaging; Ecology and Systematics; Cornell University: Ithaca, NY, USA, 1979; pp. 14850-14852.

37. Hill, M.O. Twinspan-A FORTRAN Program for Arranging Multivariate Data in an Ordered Two-Way Table by the Classification of the Individuals and Attributes. Ecology and Systematics; Cornell University: Ithaca, NY, USA, 1979; pp. 14850-14890.

38. Gauch, H.G., Jr.; Whittaker, R.H. Hierarchical classification of community data. J. Ecol. 1981, 69, 537-558. [CrossRef]

39. Ter Braak, C.J.; Smilauer, P. CANOCO Reference Manual and Canodraw for Windows User's Guide: Software for Canonical Community Ordination (Version 4.5); Biometris: Wageningen, The Netherlands, 2002; Available online: www.canoco.com (accessed on 1 April 2015).

40. Zahran, M.A.; Willis, A.J. The Vegetation of Egypt, 2nd ed.; Springer Science \& Business Media: Berlin, Germany, 2009.

41. Abd El-Gawad, A.M. Ecology and allelopathic control of Brassica tournefortii in reclaimed areas of the Nile Delta, Egypt. Turk. J. Bot. 2014, 38, 347-357. [CrossRef]

42. El-Shabasy, A.; Kasem, W. Systematic composition, species diversity and plant chorology at Wadi Tashar, Jazan, Saudi Arabia. J. Med. Plants Stud. 2018, 6, 83-88.

43. Osman, A.K.; Al-Ghamdi, F.; Bawadekji, A. Floristic diversity and vegetation analysis of Wadi Arar: A typical desert Wadi of the Northern Border region of Saudi Arabia. Saudi J. Biol. Sci. 2014, 21, 554-565. [CrossRef] [PubMed]

44. Abdel Khalik, K.; Al-Gohary, I.; Al-Sodany, Y. Floristic composition and vegetation: Environmental relationships of wadi fatimah, mecca, Saudi Arabia. Arid Land Res. Manag. 2017, 31, 316-334. [CrossRef]

45. Kasem, T.; Marei, A. Floristic Compositions and its affinities to phytogeographical regions in Wadi Khulab of Jazan, Saudi Arabia. Int. J. Plant Soil Sci. 2017, 16, 1-11. [CrossRef]

46. El Ghazali, G.E.; Al-Soqeer, A.R.A.; El Tayeb, G.E. Floristic and ecological studies on the plant cover of Wadi Al Rummah, Qassim Region, Saudi Arabia. Int. Res. J. Plant Sci. 2013, 4, 310-318.

47. Khalik, K.A.; El-Sheikh, M.; El-Aidarous, A. Floristic diversity and vegetation analysis of wadi Al-Noman, Mecca, Saudi Arabia. Turk. J. Bot. 2013, 37, 894-907. [CrossRef]

48. Clayton, W. Poales. In Flowering Plants of the World; Heywood, V.H., Ed.; Oxford University Press: Oxford, UK, 1978; pp. 285-290.

49. Jeffrey, C. Compositae. In Flowering Plants of the World; Heywood, V.H., Ed.; Oxford University Press: Oxford, UK, 1978; pp. 263-268.

50. Al-Hashim, M.H.; Taha, M.M.N.; El-Asmar, H.M. Physiographic characteristics along the Ibex Protectorate: Remote sensing application, Hotet Bani Tamim, Central Saudi Arabia. J. Environ. Earth Sci. 2019, 9, 28-42.

51. Alshammari, A.; Sharawy, S. Wild plants diversity of the Hema Faid Region (Ha'il Province, Saudi Arabia). Asian J. Plant Sci. 2010, 9, 447-454. [CrossRef]

52. Sharawy, S.M.; Alshammari, A.M. Checklist of poisonous plants and animals in Aja Mountain, Ha'il Region, Saudi Arabia. Aust. J. Basic Appl. Sci. 2009, 3, 2217-2225.

53. Habibi, K. Group dynamics of the Nubian ibex (Capra ibex nubiana) in the Tuwayiq Canyons, Saudi Arabia. J. Zool. 1997, 241, 791-801. [CrossRef]

54. Li, S.; Su, P.; Zhang, H.; Zhou, Z.; Xie, T.; Shi, R.; Gou, W. Distribution patterns of desert plant diversity and relationship to soil properties in the Heihe River Basin, China. Ecosphere 2018, 9, e02355. [CrossRef]

55. Gong, Y.; Lv, G.; Guo, Z.; Chen, Y.; Cao, J. Influence of aridity and salinity on plant nutrients scales up from species to community level in a desert ecosystem. Sci. Rep. 2017, 7, 1-12. [CrossRef]

56. Zhou, W.-L.; Yang, X.-Q.; Hao, P.; Liu, Q.-W.; Cao, D.-C.; Baribault, T.; Li, J.-W. Plant diversity and its maintenance in Populus euphratica riparian forests in the Ejina Oasis, China. Forest. Stud. China 2010, 12, 55-61. [CrossRef]

57. Wang, Z. Research on desert water management and desert control. Eur. J. Remote Sens. 2020, 53, 1-13. [CrossRef]

58. Rohit Katuri, J.; Trifonov, P.; Arye, G. Spatial distribution of salinity and sodicity in arid climate following long term brackish water drip irrigated olive orchard. Water 2019, 11, 2556. [CrossRef] 
59. Arora, S.; Dagar, J.C. Salinity tolerance indicators. In Research Developments in Saline Agriculture; Dagar, J.C., Yadav, R.K., Sharma, P.C., Eds.; Springer: Singapore, 2019; pp. 155-201.

60. Aref, I.M.; El-Juhany, L.; Hegazy, S.S. Comparison of the growth and biomass production of six acacia species in Riyadh, Saudi Arabia after 4 years of irrigated cultivation. J. Arid Environ. 2003, 54, 783-792. [CrossRef]

61. El-Sheikh, M.A.; Thomas, J.; Alatar, A.A.; Hegazy, A.K.; Abbady, G.A.; Alfarhan, A.H.; Okla, M.I. Vegetation of Thumamah Nature Park: A managed arid land site in Saudi Arabia. Rend. Lincei. 2013, 24, 349-367. [CrossRef]

62. Shaltout, K.; Mady, M. Analysis of raudhas vegetation in central Saudi Arabia. J. Arid Environ. 1996, 34, 441-454. [CrossRef]

63. Sardans, J.; Bartrons, M.; Margalef, O.; Gargallo-Garriga, A.; Janssens, I.A.; Ciais, P.; Obersteiner, M.; Sigurdsson, B.D.; Chen, H.Y.; Peñuelas, J. Plant invasion is associated with higher plant-soil nutrient concentrations in nutrient-poor environments Glob. Chang. Biol. 2017, 23, 1282-1291. [CrossRef] [PubMed]

64. Incerti, G.; Cartenì, F.; Cesarano, G.; Sarker, T.C.; El-Gawad, A.; Ahmed, M.; D'Ascoli, R.; Bonanomi, G.; Giannino, F. Faster N release, but not $C$ loss, from leaf litter of invasives compared to native species in Mediterranean ecosystems. Front. Plant Sci. 2018, 9, 534. [CrossRef] [PubMed] 